\title{
Evaluating Turkish science curriculum with PISA scientific literacy framework
}

\author{
Nurcan Cansiz \\ Artvin Çoruh University, Faculty of Education, Artvin, Turkey, nurcansiz7911@gmail.com \\ Mustafa Cansiz \\ Artvin Çoruh University, Faculty of Education, Artvin, Turkey, mustafacansiz@ gmail.com
}

\begin{abstract}
Any society needs more scientifically literate citizens even if they do not follow a career in science. In the 2015 PISA assessment, Turkey ranked $34^{\text {th }}$ among 35 OECD countries based on science literacy scores. The relatively unsuccessful results of Turkey from international level examinations like PISA has necessitated the questioning of various components of science education. One of these components is surely the science curriculum. Being aware of this, we investigated the primary and middle school Turkish science curriculum for the balance of science literacy aspects based on the PISA 2015 science literacy framework. This framework defines scientific literacy under four aspects, namely contexts, knowledge, competencies, and attitudes. The results revealed that the Turkish science curriculum does not adequately reflect all dimensions of science literacy and is dominated by the pure knowledge of the content of science. The curriculum developers should consider these two points in future curriculum revisions to increase our success in international examinations like PISA and to help raise scientifically literate students.
\end{abstract}

Keywords: $\quad$ Science literacy, Science curriculum, PISA 2015, Science education.

\section{Türkiye' de uygulanan fen bilimleri dersi öğretim programının PISA fen okuryazarlığ}

ÖZ Her toplumun -fen bilimleri alanında kariyer yapmayacak olsa bile- fen okuryazarı bireylere ihtiyacı vardır. Türkiye 2015 PISA uygulamasında fen okuryazarlığı puanına göre 35 OECD üyesi ülkeler arasında 34. sırada yer almıştır. PISA gibi uluslararası düzeyde uygulanan sınavlarda alınan görece başarısız sonuçlar, Türkiye'de fen eğitiminin farklı bileşenlerinin sorgulanmasını gerekli kılmıştır. Sınıf içi uygulamalara dönük bu bileșenlerden biri de kuşkusuz fen bilimleri dersi öğretim programıdır. Bu noktadan hareketle, bu çalışmada Türkiye'de uygulanan fen bilimleri dersi öğretim programının fen okuryazarlı̆̆ boyutlarını hangi ölçüde yansıttığı PISA 2015 Fen Okuryazarlığı Değerlendirme Çerçevesi kullanılarak araştırılmıştır. Bu çerçeve fen okuryazarlığını bağlamlar, bilgi, yeterlikler ve tutumlar olmak üzere dört boyutuyla tanımlamaktadır. Bulgular mevcut programın fen okuryazarlığın dört boyutunu dengeli bir şekilde vurgulamada yetersiz kaldığını ve programının daha çok içerik bilgisine yoğunlaştığını ortaya koymuştur. Gelecekte yapılacak program güncelleme ve geliştirme çalışmalarında bu iki noktanın göz önünde bulundurulması, hem PISA gibi uluslararası sınavlarda başarımızı artıracak, hem de fen okuryazarı öğrenciler yetiştirmede mesafeleri daha hızlı kat etmemize olanak sağlayacaktır.

Anahtar
Kelimeler: 


\section{INTRODUCTION}

The result of Programme for International Student Assessment (PISA) provided evidence that Turkish 15-year-old students are not scientifically literate enough to meet the needs of the knowledge society in which individuals are prepared as self-sufficient participants to create scientific and technological knowledge. Based on PISA 2015 statistics, most of the 15-year-old students (96.7\%) attend high schools in Turkey (OECD, 2016). That is, they successfully completed the middle school and had covered the elementary and middle school curricula already. The major goal of Turkish science curriculum is to educate scientifically literate students (Ministry of National Education [MoNE], 2004, 2013, 2017). Therefore, we expect those students to perform with a high degree of competency in PISA which evaluates the science literacy of 15-year-olds along with mathematical and reading literacy. In the 2015 PISA assessment, Turkey ranked 34th among 35 Organization for Economic Cooperation and Development (OECD) countries based on science literacy scores. Moreover, PISA 2015 result indicated that the percent of top performing students who can show advance scientific thinking and reasoning skills is less than 1\% of all 15-year-old in Turkey (OECD, 2016; Yorulmaz, Çolak, \& Ekinci, 2017). PISA describes six levels of proficiency for science literacy and identifies students as top performers at or above level 5 (OECD, 2017). The levels are arranged hierarchically in such a way that the use of content knowledge, cognitive operations, and complexity in scientific reasoning increase toward the upper levels.

It is possible to offer a number of reasons for the low success of Turkey in PISA such as the deficiency of parental support (Şad, 2012), the shortage of educational resources (OECD, 2013), low job satisfaction of teachers (Blandford, 2000), the disparity between schools (OECD, 2016), and examoriented education (Acat, Anilan, \& Anagun, 2010). Another main reason for the low success of Turkey may be the science curriculum that does not fully meet what is required to be scientifically literate. Since a curriculum is among the major sources available to teachers (Kesidou \& Roseman, 2002), they make use of curriculum in many different ways such as to find out objectives, contents, activities and the limitations for a specific topic. Moreover, it is a guide for a teacher to decide on how to teach, what to teach, when to teach, where to teach, and even why to teach. Therefore, the science curriculum should be analyzed to address inadequacies for better science education (Cansiz \& Turker, 2011; Kesidou \& Roseman, 2002). This research is significant and necessary to explore the reason behind the low scientific literacy performances of Turkish 15 -year-old students although they completed a science curriculum from grade 3 to 8 which states the scientific literacy as its major goal. Moreover, it may reveal important results from which curriculum developers and educators draw conclusions which may trigger a fundamental change for achieving scientific literacy. Considering this critical issue, we investigated whether Turkish science curriculum, released in 2017, has the potential to prepare scientifically literate students based on PISA science literacy framework.

\section{Science Literacy}

For more than five decades, many countries, especially developed ones, have attached particular importance to science literacy. Hurd (1958), for example, questioned the education system of United States by referring to the term science literacy for the first time after Soviet Union had launched the Sputnik I -the world's first artificial satellite- into Earth's orbit in 1957. From then on, the stakeholders of science education have focused on the important question of why people should be scientifically literate. Some researchers provided several reasonable arguments to this question (e.g., Durant, Evans, \& Thomas, 1989; Millar, 1996). These researchers defended that science literacy may have a profound impact on the wealth of a nation, becoming informed users of scientific knowledge in everyday life, and the use of science in public decision-making. These arguments have shaped the definition of science literacy and the characteristics of scientifically literate individuals. Although there is not a unique definition of science literacy, previous studies underlined that public should have a general sense of 
science in order to be informed and critical users of science (e.g., Kolstø, 2001; Miller, 1995, 1998). In line with this perspective, Durant (1993) underlined that science literacy refers to scientific knowledge that the societies should know to maintain their daily life. The general public does not have direct access to scientific research but in a scientifically and technologically complex culture, they ought to know something about science (Durant, 1993). National Research Council (NRC, 1996) defined a scientifically literate person as the one who can read and understand popular science articles, evaluate the trustworthiness of such articles, express opinion about socio-scientific issues, and differentiate facts from fictions.

Regarding the concerns about the level of public science literacy, the stakeholders of education have consistently focused on the science education in schools (e.g., Carlton, 1963; Collins, 1998; Fensham, 2008; Gallagher, 1971; Hurd, 1958; Rudolph \& Horibe, 2015; Yager, 1986). They have questioned if the science curriculum includes knowledge and skills to prepare students for the special needs of the times. It is specifically suggested that schools should focus more on teaching the essentials of science literacy rather than covering further content (Rutherford \& Ahlgren, 1990). Considering these warnings and recommendations, a number of reform movements were initiated to improve science education that prepares students to a "real" world. In order to improve science education, countries changed the way science is taught (Van Driel, Beijaard, \& Verloop, 2001). Instead of traditional science teaching -which includes introducing concepts, facts, theories and memorizing them- an inquiry-based science teaching was embraced including hands-on activities (Van Driel et al., 2001). It was argued that this change in science education helps students discover science topics, develop higher-order thinking skills, and be prepared for science and technological issues of the 21st century (Van Driel et al., 2001).

In 1985, the American Association for the Advancement of Science (AAAS) provided a definition for science literacy and recommendations for what students should know in science when they graduate from high school as scientifically literate individuals. Based on AAAS's (1990) definition, science literacy does not just mean knowing scientific concepts and principles; rather it has many aspects such as being aware of the environment; understanding the complex relationship between science, technology, and mathematics; having a basic understanding of science; and appreciating the subjective elements of scientific knowledge.

Almost all recent definitions of science literacy are also based on similar aspects. OECD (2016), for example, highlighted that scientifically literate society should be intellectual in that they need to approach issues scientifically. OECD intends to measure 15-year-old students' science literacy by preparing diverse assessment tools based on this definition. OECD's assessment of science literacy has awakened countries to rethink whether the science education in their schools has the standards to raise students as scientifically literate citizens. Based on such international assessments, countries are rethinking their education systems so that their students become more prepared to succeed in the $21 \mathrm{st}$ century.

\section{A Quick Look at the Science Curriculum in Turkey}

Since 2012-2103 school year, the compulsory education in Turkey has been 12 years with three stages. The first stage is the primary school which includes grades 1 to 4 . It covers children of 66 months to 10 years old (Eurydice, 2018). The middle school is the second stage including grades 5 to 8 and covers children of 10 to 14 years old. The high school, grades 9 to 12 , is the last stage before higher education. Children aged 14 to 18 years old attend high school. The type of schools in middle and high school may change. However, all students take the same science education until the end of middle school. Science education starts in the 3rd grade of primary school and continues until the 8th grade. In each grade level, all students should follow the same national curriculum. Until the recent one, the organization of the topics was based on a spiral curriculum, i.e. the topics are covered in each grade with increasing complexity by reinforcing previous learning. With the 2017 curriculum, the order of the topics has been changed in such a way that topics progress from universe to human body (see 2017 science curriculum). 
The science curriculum has been updated several times since the 2000s with the most recent revisions in 2017. In 2000, a major paradigm shift arose in many disciplines including science. Following the international reforms in science education, the national educational paradigm has shown a shift from the traditional teacher-centered approach to a contemporary student-centered approach as well. In line with this philosophy, the process of active construction of knowledge based on personal experience was underlined rather than passively acquiring it. With the changing philosophy of curriculum, education systems aim to prepare students with skills such as discovering knowledge, testing hypothesis and evaluating results, arguing and making evidence-based decisions (MoNE, 2004, 2013, 2017). In 2013, the science curriculum was revised again to include socio-scientific issues which include controversial issues related to science, technology, and society. The continuous reforms in science education resulted in new trends such as science, technology, engineering, and mathematics (STEM). The current science curriculum (i.e., 2017) focuses on STEM education for the first time. Values education is implicitly included in the curriculum, and the role of the teacher is highlighted in values education (MoNE, 2017).

\section{METHODOLOGY}

Document analysis, a type of qualitative research methods, was adopted in this study. Bowen (2009) underlined that in document analysis researchers interpret various resources (e.g., books, curriculum materials, and lesson plans) to give meaning to them. Bowen added that one of the frequent use of document analysis is to use rubric to score documents, which is what the researchers utilized within the scope of this study.

The aim of this study is to analyze the Turkish science curriculum from grades 3 to 8 to determine the emphasis given to the following aspects of science literacy: (1) contexts, (2) knowledge, (3) competencies, and (4) attitudes. The curriculum has been released in 2017 and is now being implemented in all schools in Turkey. The subject areas and the corresponding number of objectives in each grade were given in Table 1.

Table 1.

The content knowledge categories and number of objectives in 2017 Turkish science curriculum

\begin{tabular}{lcccccc}
\hline Subject Area & Grade 3 & Grade 4 & Grade 5 & Grade 6 & Grade 7 & Grade 8 \\
\hline Earth and the Universe & 5 & 5 & 9 & 5 & 10 & 3 \\
Life and Living Things & 11 & 8 & 8 & 20 & 17 & 28 \\
Physical phenomena & 16 & 20 & 14 & 19 & 27 & 16 \\
Matter and Its Nature & 4 & 10 & 6 & 13 & 16 & 17 \\
Science and Engineering Practices & - & 3 & 3 & 4 & 4 & 4 \\
Total & 36 & 46 & 40 & 61 & 74 & 68 \\
\hline
\end{tabular}




\section{Instrument: Science Literacy Framework of PISA 2015}

For the purpose of this study, the objectives of science curriculum from grades 3 to 8 were analyzed and categorized using the PISA 2015 science literacy framework. PISA has introduced the four aspects of science literacy as the contexts, the knowledge, the competencies, and the attitudes (OECD, 2016). The framework in Table 2 presents the aspects of science literacy and the explanations for each aspect based on PISA 2015 Assessment and Analytical Framework.

Table 2.

PISA 2015 science literacy assessment framework

\begin{tabular}{ll}
\hline $\begin{array}{c}\text { Science } \\
\text { Literacy Aspect }\end{array}$ & \multicolumn{1}{c}{ Description } \\
\hline Contexts & $\begin{array}{l}\text { Personal, local/national and global issues, both current and historical, which demand some } \\
\text { understanding of science and technology } \\
\text { An understanding of the major facts, concepts and explanatory theories that form the basis } \\
\text { of scientific knowledge. Such knowledge includes knowledge of both the natural world } \\
\text { and technological artefacts (content knowledge), knowledge of how such ideas are } \\
\text { produced (procedural knowledge), and an understanding of the underlying rationale for } \\
\text { these procedures and the justification for their use (epistemic knowledge) } \\
\text { The ability to explain phenomena scientifically, evaluate and design scientific enquiry, and } \\
\text { interpret data and evidence scientifically. } \\
\text { A set of attitudes towards science indicated by an interest in science and technology, } \\
\text { valuing scientific approaches to enquiry where appropriate, and a perception and awareness } \\
\text { of environmental issues. }\end{array}$ \\
\hline
\end{tabular}

The four dimensions presented in Table 2 have also subdimensions. Moreover, each subdimension includes several practices that a scientifically literate person is capable of doing. For example, the competencies aspect has three subdimensions as explain phenomena scientifically, evaluate and design scientific enquiry, and interpret data and evidence scientifically. The subdimension explain phenomena scientifically has also several practices and one of them is recall and apply appropriate scientific knowledge. That is, a scientifically literate person should have scientific competencies and one of which is to be able to explain phenomena scientifically. To achieve this, he/she should recall and apply appropriate scientific knowledge. Each dimension including subdimensions and practices are provided in Appendix 1.

\section{The Analysis Procedure}

We analyzed the objectives of each unit from Grade 3 to Grade 8 using the framework in Table 2. Two independent researchers examined each science curriculum to determine the distribution of the four aspects of science literacy. Before the analysis, they examined the science literacy framework for clarifications and scoring process. They analyzed a number of objectives together to use the same analysis criterion and scoring procedure. They performed analysis by assigning each objective to one of the four aspects of the framework. After researchers completed the analysis of each curriculum independently, they compared their findings to reconcile their decisions. At the beginning, there were 41 inconsistencies out of 432 decisions. Therefore, the interrater reliability was calculated as $90.51 \%$. Then Cohen's Kappa (Cohen, 1960) was administered to test the significance of this interrater reliability. The interrater reliability was statistically significant (Cohen's Kappa $=.78, p<.001$ ). Based on Landis and Koch's (1977) criteria, the level of agreement was substantial. In the end, full reconciliation occurred in the analysis of the objectives. It is worth mentioning that one objective can be assigned to more than one aspect of science literacy. Therefore, the total frequencies given in the results section should not necessarily be equal to the total number of objectives for each grade in the curriculum.

A step by step procedure was presented below to exemplify the analysis of objectives. An objective was focused, e.g. "students discover the materials that are attracted to magnets by doing experiments" (Objective number: F.4.3.2.2). 
Each researcher read it carefully and decided whether it emphasizes content, competency, or attitude aspect. Two researchers decided that it emphasizes competency aspect.

It was then decided to which subdimension it belongs to under competency aspect. This objective requires that students interpret data and evidence scientifically (a subdimension of competency aspect) since they will experiment with different materials and magnets. As a result, they will have data on which materials are attracted or not attracted to magnets.

After reaching consensus on subdimension, the researchers focused on which practice the objective belongs to under the subdimension. This objective was assigned to the practice "analyze and interpret data and draw appropriate conclusions" because students experiment with different kind of materials and magnets, collect data on which of them are attracted to the magnets and draw conclusions about the materials that are attracted to the magnets.

This objective was also assigned to the content aspect of scientific literacy. It was in physical science subdimension.

Finally, it was decided that it is written free from a context.

A similar pattern was followed during the analysis of all objectives. The Figure 1 summarizes the data analysis process of objectives.

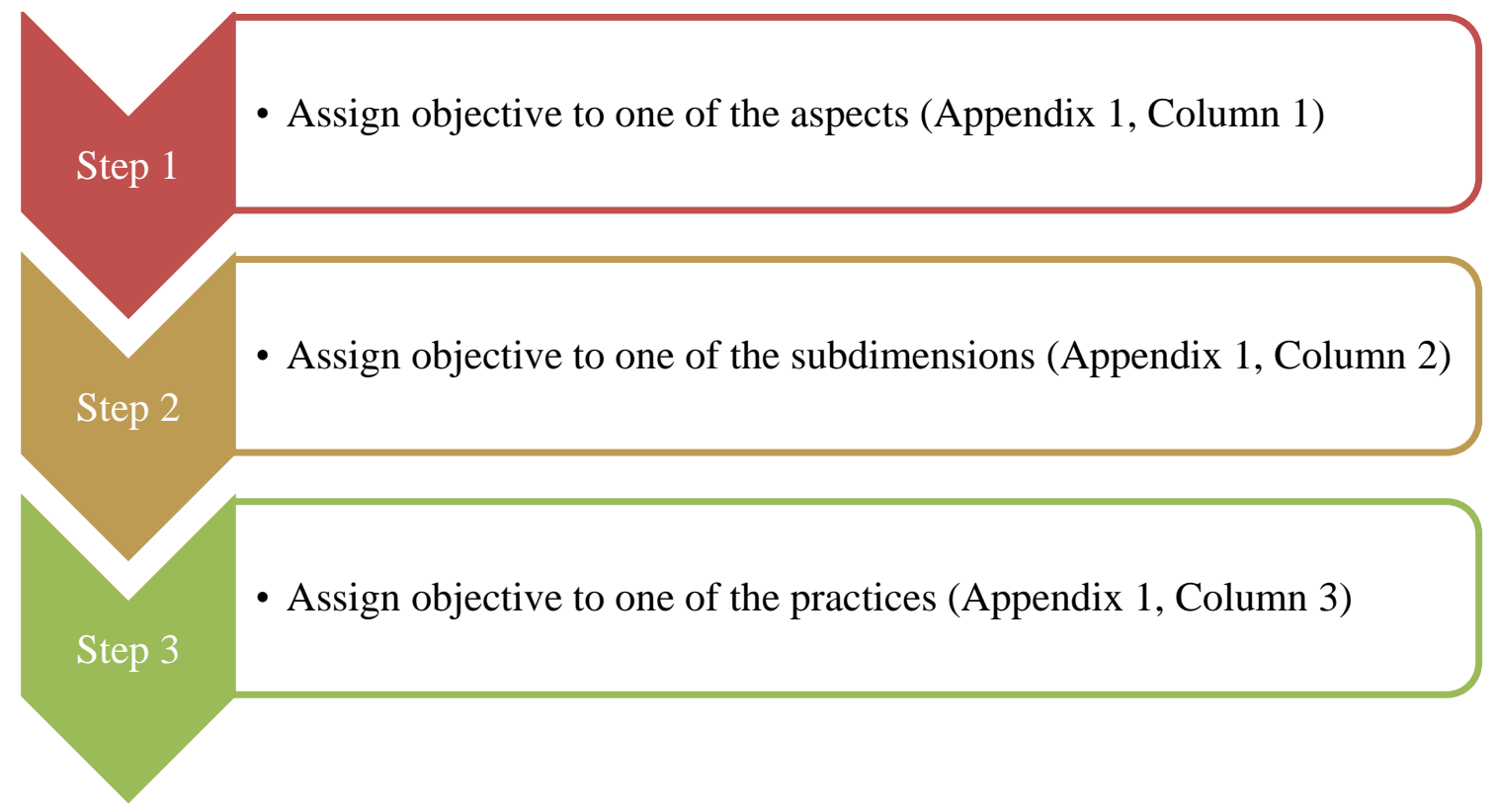

Figure 1. The data analysis process

\section{RESULTS}

The present study was designed to determine the extent to which Turkish science curriculum emphasizes the PISA 2015 science literacy aspects. With this in mind, we classified the objectives in Turkish science curriculum for grades 3 to 8 . Table 3 shows the results of data analysis which reveals the frequencies and percentages in each aspect of science literacy. 
Table 3.

The distribution of objectives in each aspect of science literacy from grade 3 to 8

\begin{tabular}{|c|c|c|c|c|c|c|c|c|c|c|c|c|}
\hline & \multicolumn{2}{|c|}{ Grade 3} & \multicolumn{2}{|c|}{ Grade 4} & \multicolumn{2}{|c|}{ Grade 5} & \multicolumn{2}{|c|}{ Grade 6} & \multicolumn{2}{|c|}{ Grade 7} & \multicolumn{2}{|c|}{ Grade 8} \\
\hline & $\mathrm{f}$ & $\%$ & $\mathrm{f}$ & $\%$ & $\mathrm{f}$ & $\%$ & $f$ & $\%$ & $\mathrm{f}$ & $\%$ & $\mathrm{f}$ & $\%$ \\
\hline \multicolumn{13}{|l|}{ Contexts } \\
\hline Personal & 7 & 19.4 & 6 & 13.0 & - & - & 3 & 4.9 & 1 & 1.4 & 1 & 1.5 \\
\hline Local/National & 1 & 2.8 & 4 & 8.7 & 2 & 5.0 & 5 & 8.2 & 4 & 5.4 & 8 & 11.8 \\
\hline Global & - & - & 7 & 15.2 & 3 & 7.5 & 2 & 3.3 & - & - & 3 & 4.4 \\
\hline Total & 8 & 22.2 & 17 & 36.9 & 5 & 12.5 & 10 & 16.4 & 5 & 6.8 & 12 & 17.7 \\
\hline \multicolumn{13}{|l|}{ Knowledge } \\
\hline Knowledge of the Content of Science & 22 & 61.1 & 15 & 32.6 & 10 & 25.0 & 27 & 44.3 & 36 & 48.6 & 31 & 45.6 \\
\hline Procedural Knowledge & 10 & 27.7 & 6 & 13.0 & 13 & 32.5 & 8 & 13.1 & 6 & 8.1 & 9 & 13.2 \\
\hline Epistemic knowledge & 1 & 2.8 & - & - & - & - & - & - & 2 & 2.7 & - & - \\
\hline Total & 33 & 91.6 & 21 & 45.6 & 23 & 57.5 & 35 & 57.4 & 44 & 59.4 & 40 & 58.8 \\
\hline \multicolumn{13}{|l|}{ Competencies } \\
\hline Explain phenomena scientifically & 10 & 27.7 & 16 & 34.8 & 10 & 25.0 & 18 & 29.5 & 19 & 25.7 & 17 & 25.0 \\
\hline Evaluate and design scientific inquiry & 1 & 2.8 & 6 & 13.0 & 3 & 7.5 & - & - & 1 & 1.4 & 4 & 5.9 \\
\hline Interpret data and evidence scientifically & 3 & 8.3 & 10 & 21.7 & 5 & 12.5 & 4 & 6.6 & 6 & 8.1 & 3 & 4.4 \\
\hline Total & 14 & 38.8 & 32 & 69.5 & 18 & 45.0 & 22 & 36.1 & 26 & 35.2 & 24 & 35.3 \\
\hline \multicolumn{13}{|l|}{ Attitudes } \\
\hline Interest in science & - & - & - & - & - & - & - & - & - & - & - & - \\
\hline Valuing scientific approaches to enquiry & 2 & 5.6 & 1 & 2.2 & 1 & 2.5 & 4 & 6.6 & - & - & 5 & 7.4 \\
\hline Environmental awareness & 4 & 11.1 & 8 & 17.4 & 5 & 12.5 & 2 & 3.3 & 6 & 8.1 & 5 & 7.4 \\
\hline Total & 6 & 16.7 & 9 & 20.2 & 6 & 15.0 & 6 & 9.9 & 6 & 8.1 & 10 & 14.8 \\
\hline
\end{tabular}

Table 3 shows that objectives in all grades rarely include personal, local, or global issues. In grade three, only eight objectives (out of 36) are based on a context. These numbers vary in different grades: in fourth grade, 17 objectives (out of 46); in fifth grade, five objectives (out of 40); in sixth grade, 10 objectives (out of 61); in seventh grade, five objectives (out of 74); and in eighth grade, 12 objectives (out of 68) include personal, local, or global context. These contexts are important since how students use knowledge and competencies in these specific contexts is the main idea underlying science literacy.

The analysis of the objectives in terms of the knowledge aspect of science literacy revealed that the content knowledge is represented more than other two knowledge categories (see Table 3). The least emphasis is on epistemic knowledge. Only in grade five, the emphasis on procedural knowledge is higher than content and epistemic knowledge.

The percentage distribution based on scientific competencies showed that the most emphasis is on explain phenomena scientifically (see Table 3). The other two competencies -evaluate and design scientific inquiry- are emphasized least in the curriculum for all grades except grade eight.

Attitudes aspect of science literacy is given the least emphasis among other aspects. Moreover, objectives mostly focus on environmental awareness among other dimensions of attitude. Table 3 gives an overall distribution of objectives based on four aspects of science literacy. We provided in-depth results including typical objectives for each aspect in the following sections.

\section{Contexts in the Science Curriculum}

Regarding the context aspect of science literacy, the percentage distribution was presented in Table 4. The minus (-) sign in the cells of tables refers to the fact that the curriculum does not include any objectives corresponding to that cell. The result is notable in that there are not adequate context-based objectives in Turkish science curriculum. That is, there are few objectives including personal, local and global contexts. Among them, health issues at personal level are represented more than others. At global level, on the other hand, environmental quality is emphasized more than others. Natural resources are emphasized at local level most. However, the frequencies for different contexts at each level are very low as compared to the total number of objectives. Typical objectives for contexts dimension are provided in Appendix 2. 
Table 4.

The frequencies of the context of objectives from grade 3 to 8

\begin{tabular}{|c|c|c|c|c|c|c|c|c|c|c|c|c|}
\hline & \multicolumn{2}{|c|}{ Grade 3} & \multicolumn{2}{|c|}{ Grade 4} & \multicolumn{2}{|c|}{ Grade 5} & \multicolumn{2}{|c|}{ Grade 6} & \multicolumn{2}{|c|}{ Grade 7} & \multicolumn{2}{|c|}{ Grade 8} \\
\hline & $\mathrm{f}$ & $\%$ & $\mathrm{f}$ & $\%$ & $\mathrm{f}$ & $\%$ & $\mathrm{f}$ & $\%$ & $\mathrm{f}$ & $\%$ & $\mathrm{f}$ & $\%$ \\
\hline \multicolumn{13}{|l|}{ Personal } \\
\hline Health and Disease & 4 & 11.1 & 4 & 8.7 & - & - & 3 & 4.9 & - & - & 1 & 1.5 \\
\hline Natural Resources & - & - & - & - & - & - & - & - & - & - & - & - \\
\hline Environmental Quality & 1 & 2.8 & 2 & 4.3 & - & - & - & - & - & - & - & - \\
\hline Hazards & 2 & 5.6 & - & - & - & - & - & - & - & - & - & - \\
\hline Frontiers of Science and Technology & - & - & - & - & - & - & - & - & - & - & - & - \\
\hline Total & 7 & 19.5 & 6 & 13.0 & - & - & 3 & 4.9 & - & - & 1 & 1.5 \\
\hline \multicolumn{13}{|l|}{ Local } \\
\hline Health and Disease & - & - & 1 & 2.2 & - & - & 2 & 3.3 & - & - & 1 & 1.5 \\
\hline Natural Resources & - & - & 2 & 4.3 & - & - & 1 & 1.6 & 1 & 1.4 & 3 & 4.4 \\
\hline Environmental Quality & 1 & 2.8 & & & 1 & 2.5 & 1 & 1.6 & 1 & 1.4 & 2 & 2.9 \\
\hline Hazards & - & - & - & - & - & - & - & - & - & - & - & - \\
\hline Frontiers of Science and Technology & - & - & 1 & 2.2 & - & - & 1 & 1.6 & 2 & 2.7 & 2 & 2.9 \\
\hline Total & 1 & 2.8 & 4 & 8.7 & 1 & 2.5 & 5 & 8.1 & 4 & 5.5 & 8 & 11.7 \\
\hline \multicolumn{13}{|l|}{ Global } \\
\hline Health and Disease & - & - & - & - & - & - & - & - & - & - & - & - \\
\hline Natural Resources & - & - & - & - & - & - & 1 & 1.6 & - & - & - & - \\
\hline Environmental Quality & - & - & 7 & 15.2 & 3 & 7.5 & 1 & 1.6 & - & - & - & - \\
\hline Hazards & - & - & - & - & - & - & - & - & - & - & 3 & 4.4 \\
\hline Frontiers of Science and Technology & - & - & - & - & - & - & - & - & - & - & - & - \\
\hline Total & - & - & 7 & 15.2 & 3 & 7.5 & 2 & 3.2 & - & - & 3 & 4.4 \\
\hline
\end{tabular}

\section{Knowledge Aspect of Objectives}

Table 5 displays the distribution of the knowledge aspect of science literacy. As mentioned before, the knowledge aspect has three subdimensions as content, procedural, and epistemic knowledge. The objectives in the content dimension only cover the facts, principles or theories rather than apply them in contexts. For example, one of the objectives in grade five is as follows: students "explain the main differences between heat and temperature" (MoNE, 2017, p. 28). The emphasis in this objective is only on the facts of science. There is no reference to procedural or epistemic knowledge of science. In all grades, the subdimension procedural knowledge is observed less in the objectives as compared to the content knowledge. There are more objectives including measurement issues compared to others under procedural knowledge. The other more frequent procedural knowledge is the use of control variables and identifying possible causal mechanisms. However, the objectives very rarely include the epistemic dimension of scientific knowledge. Only two objectives emphasize the reasoning based on data (see Appendix 3 for typical objectives for knowledge dimension). 
Table 5.

The frequencies of the knowledge aspects of objectives from grade 3 to 8

\begin{tabular}{|c|c|c|c|c|c|c|c|c|c|c|c|c|}
\hline & \multicolumn{2}{|c|}{ Grade 3} & \multicolumn{2}{|c|}{ Grade 4} & \multicolumn{2}{|c|}{ Grade 5} & \multicolumn{2}{|c|}{ Grade 6} & \multicolumn{2}{|c|}{ Grade 7} & \multicolumn{2}{|c|}{ Grade 8} \\
\hline & $\mathrm{f}$ & $\%$ & f & $\%$ & $\mathrm{f}$ & $\%$ & $\mathrm{f}$ & $\%$ & $\mathrm{f}$ & $\%$ & $\mathrm{f}$ & $\%$ \\
\hline \multicolumn{13}{|l|}{ Knowledge of the Content of } \\
\hline \multicolumn{13}{|l|}{ Science } \\
\hline Physical systems & 12 & 33.3 & 8 & 17.4 & 4 & 10.0 & 9 & 14.8 & 17 & 23.0 & 17 & 25.0 \\
\hline Living System & 6 & 16.7 & 2 & 4.3 & 1 & 2.5 & 15 & 24.6 & 12 & 16.2 & 11 & 16.2 \\
\hline Earth and Space System & 4 & 11.1 & 5 & 10.9 & 5 & 12.5 & 3 & 4.9 & 7 & 9.5 & 3 & 4.4 \\
\hline Total & 22 & 61.1 & 15 & 32.6 & 10 & 25.0 & 27 & 44.3 & 36 & 48.7 & 31 & 45.6 \\
\hline \multicolumn{13}{|l|}{ Procedural Knowledge } \\
\hline The concept of variables & - & - & - & - & 2 & 5.0 & 2 & 3.3 & 1 & 1.4 & 1 & 1.5 \\
\hline Concepts of Measurements & 7 & 19.4 & 5 & 10.9 & 8 & 20.0 & 3 & 4.9 & 5 & 6.8 & 4 & 5.9 \\
\hline $\begin{array}{l}\text { Ways of assessing and minimizing } \\
\text { uncertainty }\end{array}$ & - & - & - & - & - & - & - & - & - & - & - & - \\
\hline $\begin{array}{l}\text { Mechanisms to ensure the } \\
\text { replicability of data }\end{array}$ & - & - & - & - & - & - & - & - & - & - & - & - \\
\hline $\begin{array}{l}\text { Common ways of abstracting and } \\
\text { representing data }\end{array}$ & - & - & - & - & - & - & 1 & 1.6 & - & - & 2 & 2.9 \\
\hline The control-of-variables & 3 & 8.3 & 1 & 2.2 & 3 & 7.5 & 2 & 3.3 & - & - & 2 & 2.9 \\
\hline $\begin{array}{l}\text { The nature of an appropriate } \\
\text { design for a scientific question }\end{array}$ & - & - & - & - & - & - & - & - & - & - & - & - \\
\hline Total & 10 & 27.7 & 6 & 13.1 & 13 & 32.5 & 8 & 13.1 & 6 & 8.2 & 9 & 13.2 \\
\hline \multicolumn{13}{|l|}{ Epistemic knowledge } \\
\hline $\begin{array}{l}\text { The nature of scientific } \\
\text { observations, facts, hypotheses, } \\
\text { models, and theories }\end{array}$ & - & - & - & - & - & - & - & - & - & - & - & - \\
\hline $\begin{array}{l}\text { The purpose and goals of science } \\
\text { as distinguished from technology }\end{array}$ & - & - & - & - & - & - & - & - & - & - & - & - \\
\hline The values of science & - & - & - & - & - & - & - & - & - & - & - & - \\
\hline The nature of reasoning & - & - & - & - & - & - & - & - & - & - & - & - \\
\hline $\begin{array}{l}\text { How scientific claims are } \\
\text { supported by data }\end{array}$ & 1 & 2.8 & - & - & - & - & - & - & 1 & 1.4 & - & - \\
\hline $\begin{array}{l}\text { The function of different forms of } \\
\text { empirical enquiry }\end{array}$ & - & - & - & - & - & - & - & - & - & - & - & - \\
\hline $\begin{array}{l}\text { How measurement error affects } \\
\text { the degree of confidence }\end{array}$ & - & - & - & - & - & - & - & - & 1 & 1.4 & - & - \\
\hline $\begin{array}{l}\text { The use and role of abstract } \\
\text { models and their limits }\end{array}$ & - & - & - & - & - & - & - & - & - & - & - & - \\
\hline $\begin{array}{l}\text { The role of collaboration and } \\
\text { critique }\end{array}$ & - & - & - & - & - & - & - & - & - & - & - & - \\
\hline $\begin{array}{l}\text { The role of scientific knowledge, } \\
\text { along with other forms of } \\
\text { knowledge }\end{array}$ & - & - & - & - & - & - & - & - & - & - & - & - \\
\hline Total & 1 & 2.8 & - & - & - & - & - & - & 2 & 2.8 & - & - \\
\hline
\end{tabular}

\section{Scientific Competencies}

PISA 2015 framework introduces scientific competencies as an aspect of science literacy including three subdimensions (OECD, 2017). In the objectives, the most emphasized competency is explaining phenomena scientifically. The other competencies are seldom emphasized in the objectives as seen in Table 6. In terms of subdimension interpret data and evidence scientifically, the emphasis in the objectives is only on the ability to analyze and interpret data and draw appropriate conclusions. Considering the subdimension evaluate and design scientific inquiry, the emphasis in the objectives is only on the ability to propose a way of exploring a given question scientifically. Typical objectives for scientific competencies dimension are provided in Appendix 4. 
Table 6.

The frequencies of the objectives in competencies aspect from grade 3 to 8

\begin{tabular}{|c|c|c|c|c|c|c|c|c|c|c|c|c|}
\hline & \multicolumn{2}{|c|}{ Grade 3} & \multicolumn{2}{|c|}{ Grade 4} & \multicolumn{2}{|c|}{ Grade 5} & \multicolumn{2}{|c|}{ Grade 6} & \multicolumn{2}{|c|}{ Grade 7} & \multicolumn{2}{|c|}{ Grade 8} \\
\hline & $\mathrm{f}$ & $\%$ & $\mathrm{f}$ & $\%$ & $\mathrm{f}$ & $\%$ & $\mathrm{f}$ & $\%$ & $\mathrm{f}$ & $\%$ & $\mathrm{f}$ & $\%$ \\
\hline \multicolumn{13}{|l|}{ Explain phenomena scientifically } \\
\hline $\begin{array}{l}\text { Recall and apply appropriate scientific } \\
\text { knowledge. }\end{array}$ & 4 & 11.1 & 4 & 8.7 & 1 & 2.5 & 6 & 9.8 & 7 & 9.5 & 6 & 8.8 \\
\hline $\begin{array}{l}\text { Identify, use and generate explanatory } \\
\text { models and representations }\end{array}$ & 2 & 5.6 & - & - & 7 & 17.5 & 3 & 4.9 & 5 & 6.8 & 2 & 2.9 \\
\hline $\begin{array}{l}\text { Make and justify appropriate } \\
\text { predictions }\end{array}$ & 1 & 2.8 & 1 & 2.2 & 2 & 5.0 & 6 & 9.8 & 3 & 4.1 & 4 & 5.9 \\
\hline Offer explanatory hypotheses & 2 & 5.6 & - & - & - & - & 1 & 1.6 & - & - & - & - \\
\hline $\begin{array}{l}\text { Explain the potential implications of } \\
\text { scientific knowledge for society }\end{array}$ & 1 & 2.8 & 11 & 23.9 & - & - & 2 & 3.3 & 4 & 5.4 & 5 & 7.4 \\
\hline Total & 10 & 27.9 & 16 & 34.8 & 10 & 25.0 & 18 & 29.4 & 19 & 25.8 & 17 & 25.0 \\
\hline \multicolumn{13}{|l|}{ Evaluate and design scientific enquiry } \\
\hline $\begin{array}{l}\text { Identify the question explored in a } \\
\text { given scientific study. }\end{array}$ & - & - & - & - & - & - & - & - & - & - & - & - \\
\hline $\begin{array}{l}\text { Distinguish questions that could be } \\
\text { investigated scientifically }\end{array}$ & - & - & - & - & - & - & - & - & - & - & - & - \\
\hline $\begin{array}{l}\text { Propose a way of exploring a given } \\
\text { question scientifically }\end{array}$ & 1 & 2.8 & 6 & 13.0 & 3 & 7.5 & - & - & 1 & 1.4 & 4 & 5.9 \\
\hline $\begin{array}{l}\text { Evaluate ways of exploring a given } \\
\text { question scientifically }\end{array}$ & - & - & - & - & - & - & - & - & - & - & - & - \\
\hline $\begin{array}{l}\text { Describe and evaluate how scientists } \\
\text { ensure the reliability of data and the } \\
\text { objectivity and generalizability of } \\
\text { explanations }\end{array}$ & - & - & - & - & - & - & - & - & - & - & - & - \\
\hline Total & 1 & 2.8 & 6 & 13.0 & 3 & 7.5 & - & - & 1 & 1.4 & 4 & 5.9 \\
\hline \multicolumn{13}{|l|}{ Interpret data and evidence scientifically } \\
\hline $\begin{array}{l}\text { Transform data from one } \\
\text { representation to another }\end{array}$ & - & - & - & - & - & - & - & - & - & - & - & - \\
\hline $\begin{array}{l}\text { Analyze and interpret data and draw } \\
\text { appropriate conclusions }\end{array}$ & 3 & 8.3 & 10 & 21.7 & 5 & 12.5 & 4 & 6.6 & 6 & 8.1 & 3 & 4.4 \\
\hline $\begin{array}{l}\text { Identify the assumptions, evidence, } \\
\text { and reasoning in science-related texts. }\end{array}$ & - & - & - & - & - & - & - & - & - & - & - & - \\
\hline $\begin{array}{l}\text { Distinguish between arguments that } \\
\text { are based on scientific evidence and } \\
\text { theory and those based on other } \\
\text { considerations. }\end{array}$ & - & - & - & - & - & - & - & - & - & - & - & - \\
\hline $\begin{array}{l}\text { Evaluate scientific arguments and } \\
\text { evidence from different sources }\end{array}$ & - & - & - & - & - & - & - & - & - & - & - & - \\
\hline Total & 3 & 8.3 & 10 & 21.7 & 5 & 12.5 & 4 & 6.6 & 6 & 8.1 & 3 & 4.4 \\
\hline
\end{tabular}

\section{Attitudes Aspect}

Table 7 gives the frequencies and percentage distribution of objectives for attitudes aspect of science literacy. The objectives mostly focus on environmental awareness with a high percentage in grade four. There is no explicit reference to the aspect interest in science in any grade (see Appendix 5 for typical objectives for attitude dimension).

Table 7.

The frequencies of the objectives in attitude aspect from grade 3 to 8

\begin{tabular}{lcccccccccccc}
\hline & \multicolumn{2}{c}{ Grade 3 } & Grade 4 & \multicolumn{2}{c}{ Grade 5 } & \multicolumn{2}{c}{ Grade 6 } & \multicolumn{2}{c}{ Grade 7 } & \multicolumn{2}{c}{ Grade 8 } \\
\cline { 2 - 14 } & $\mathrm{f}$ & $\%$ & $\mathrm{f}$ & $\%$ & $\mathrm{f}$ & $\%$ & $\mathrm{f}$ & $\%$ & $\mathrm{f}$ & $\%$ & $\mathrm{f}$ & $\%$ \\
\hline Interest in science & - & - & - & - & - & - & - & - & - & - & - & - \\
Valuing scientific approaches to enquiry & 2 & 5.6 & 1 & 2.2 & 1 & 2.5 & 4 & 6.6 & - & - & 5 & 7.4 \\
Environmental awareness & 4 & 11.1 & 8 & 17.4 & 5 & 12.5 & 2 & 3.3 & 6 & 8.1 & 5 & 7.4 \\
Total & 6 & 16.7 & 9 & 19.6 & 6 & 15.0 & 6 & 9.9 & 6 & 8.1 & 10 & 14.8 \\
\hline
\end{tabular}




\section{DISCUSSION}

This research was designed to explore the extent to which 2017 Turkish science curriculum supports the development of scientifically literate students. The objectives from grade 3 to 8 were closely scrutinized for their emphasis given on the aspects of science literacy as defined by PISA. Since science curriculum is the major source that provides the outcomes about what is taught in science classrooms to a great extent, we expect that this study offers some important contribution to both teacher educators and curriculum developers.

There are two main overall findings of this study. One of the most significant findings to emerge from this study is that Turkish science curriculum reflects the aspects of science literacy in varying degrees. That is, the curriculum is not adequate to reflect each of the four dimensions in a balanced manner. The results of this study revealed that the context aspect of the science literacy framework of PISA is almost not included in the objectives of Turkish science curriculum. However, active engagement of students with real-world contexts that affect their lives is seriously highlighted in the definition of science literacy. In other words, the definition of science literacy highlights context-driven curriculum. This context-driven curriculum in science teaching aims to engage students with issues that they are highly likely to come across as citizens (Roberts, 2007). The science curriculum that is contextualized around real-world problems is needed to help students develop a more realistic understanding of the world around them by adapting to a wider social and cultural reality in science classrooms. Lack of a realworld context may lead to a feeling that the concepts learned in schools are not related to daily life. The context-driven science helps students to find out the underlying science concepts for real-world issues (Fensham, 2009). Moreover, choosing the contexts compatible with students' daily lives results in the generation of intrinsic interests (Fensham, 2009). Especially personal and local contexts are valuable to make sense of the world around us and global context to understand others' world.

The second important finding of this study was about the emphasis given on the knowledge aspect. The three subdimensions of knowledge aspect are represented in varying degrees. The most emphasis is given to the content knowledge while the epistemic knowledge is emphasized least. The objectives mostly include the memorizing of the scientific facts and principles. The emphasis on the science content may be important but it should be balanced with procedural and epistemic knowledge. The science curriculum is particularly deficient in providing students with experiences for procedural and epistemic knowledge. In order to meet the needs of the 21 st century, the curriculum should be readjusted to underlie these two types of knowledge. The industry world in the 21 st century requires people with diverse skills such as creating testable hypothesis, design experiments to test the hypothesis, manipulate variables, and collect data (Duggan \& Gott, 2002). Citizens can gain these skills through practicing during K-12 education, primarily in science classrooms. Especially the reforms in science education underline the process of science and students' understanding of how scientific knowledge is produced (e.g., AAAS, 1989, 1993; NRC, 1996). Students should develop certain abilities for scientific inquiry. These abilities cannot be separated from science content and yet there is no need to choose skills over content (Rillero, 1998). It is obvious that procedural knowledge is necessary to do science. This, in turn, will lead to produce first-hand science knowledge. Students cannot link the procedural knowledge and content knowledge if there is less emphasis on procedural knowledge. The objectives of the curriculum are also problematic in terms of epistemic knowledge. Students who experience the Turkish science curriculum do not have adequate epistemic knowledge of science until Grade 8 because it is not highlighted in the curriculum until then. Epistemic knowledge is related to the nature and characteristics of scientific knowledge. As content and procedural knowledge, it is an eminent aspect of science literacy. The reforms in science education have brought the idea of inquiry-based science teaching in order to introduce students to the procedural knowledge and skills in science. An inquiry is defined as complex activity that contains numerous skills such as asking questions, observing the environment, reviewing literature about what is previously known, collecting data, interpreting the evidence, and evaluating alternative solutions (NRC, 1996). Inquiry refers to the way how scientists work and to the 
methodology of science teaching and learning (Carlson, Humphrey, \& Reinhardt, 2003). Therefore, the science curriculum should include objectives promoting inquiry-based practices if it aims to promote science literacy.

Regarding scientific competencies, the Turkish science curriculum emphasizes mostly explain phenomena scientifically and seldom focus on other two aspects -evaluate and design scientific inquiry, interpret data and evidence scientifically. As discussed in the knowledge aspect above, the three competencies should share equal importance. Therefore, students need to experience all of them with similar emphasis. In addition to having knowledge of scientific concepts, science literacy requires the ability to carry out a scientific inquiry. The discussions on science literacy also confirm this viewpoint. For example, when Roberts (2007) suggested the two visions of science literacy, he aimed to emphasize both contents of science (vision I) and the use of these contents (vision II). Therefore, there is a need for a science curriculum that provides students with opportunities to conduct scientific inquiry in which they utilize content, procedural, and epistemic knowledge together. In this way, they can evaluate their results and reach meaningful conclusions.

Among others, the most neglected aspect of science literacy is attitudes aspect. Regarding three subdimensions of this aspect, only the fourth-grade science curriculum includes objectives emphasizing environmental awareness while science curriculum from six to eight grade emphasizes neither of them. The attitudes towards science are generally neglected in science curriculum because the cognitive gains are given more emphasis than affective ones. However, having positive attitudes toward science bring about other outcomes such as science achievement. Moreover, Kirk (2018) underlined that if the learning environment only offers students cognitive opportunity to learn, then it is highly likely that such environment may inhibit students' learning at a certain point in time. If students appreciate science and scientific way of thinking, they become more scientifically literate. A key policy priority should, therefore, be to consider the ways of promoting students' attitudes toward science which, in turn, promotes science literacy.

\section{CONCLUSION and RECOMMENDATIONS}

The present study was designed to evaluate the extent to which Turkish science curriculum emphasizes the PISA 2015 science literacy aspects. Overall, the investigation of objectives has shown that there are certain drawbacks of current science curriculum in terms of raising scientifically literate children. The most significant finding of this study is that Turkish science curriculum includes objectives fostering content knowledge more. That is, the curriculum is dominated by the pure knowledge of the content of science. This is definitely an essential element of science education but there is a need to focus on the process of science in classrooms.

The Turkish science curriculum underlines the importance of educating every young person as scientifically literate. However, the evidence from this study indicated that this is not totally reflected in the objectives. Although current science curriculum emphasizes science literacy and include objectives fostering it to some degree, international assessments show that Turkish students (especially 15-yearold ones) are not well-equipped with the elements of science literacy. Therefore, Turkish science curriculum in each grade needs to be redesigned to provide students with opportunities to raise them science literacy in all aspects. It should include objectives fostering each aspect of science literacy in a balanced manner. Lack of such curriculum might be one of the reasons why 15 -year-old students in Turkey "fail" in PISA assessments. 


\section{REFERENCES}

Acat, M. B., Anılan, H., \& Anagun, S. S. (2010). The problems encountered in designing constructivist learning environments in science education and practical suggestions. The Turkish Online Journal of Educational Technology, 9(2), 212-220.

American Association for the Advancement of Science [AAAS]. (1989). Science for all Americans. New York: Oxford University Press.

American Association for the Advancement of Science [AAAS]. (1990). Science for all Americans. New York: Oxford University Press.

American Association for the Advancement of Science [AAAS]. (1993) Benchmarks for science literacy. New York: Oxford University Press.

Blandford, S. (2000). Managing professional development in schools. London: Routledge.

Bowen, G. A. (2009). Document analysis as a qualitative research method. Qualitative Research Journal, 9(2), 27-40. DOI: https://doi.org/10.3316/QRJ0902027

Carlson, M. O. B., Humphrey, G. E., \& Reinhardt, K. (2003). Weaving science inquiry and continuous assessment: Using formative assessment to improve learning. California: Corwin Press.

Carlton, R. (1963). On scientific literacy. NEA Journal, 52(4) 33-35.

Cansiz, M., \& Turker, N. (2011). Scientific literacy investigation in science curricula: The case of Turkey. Western Anatolia Journal of Educational Sciences, Special Issue, 359-366.

Collins, A. (1998). National science education standards: A political document. Journal of Research in Science Teaching, 35(7), 711-727. DOI: https://doi.org/10.1002/(SICI)1098-2736(199809)35:7<711: AIDTEA3>3.0.CO;2-O

Duggan S., \& Gott, R. (2002). What sort of science education do we really need? International Journal of Science Education, 24(7), 661-679. DOI: https://doi.org/10.1080/09500690110110133

Durant, J. R. (1993). What is scientific literacy? In J. R. Durant \& J. Gregory (Eds.), Science and culture in Europe (pp. 129-137). London: Science Museum.

Durant, J. R., Evans, G., \& Thomas, G. P. (1989). The public understanding of science. Nature, 340(6228), 1114. DOI: https://doi.org/10.1038/340011a0

Eurydice (2018). Basic characteristics of education system: Turkey overview. Retrieved September, 10, from https://eacea.ec.europa.eu/national-policies/eurydice/content/turkey_cs.

Fensham, P. J. (2008). Science education policy-making. Paris: UNESCO.

Fensham, P. J. (2009) Real world contexts in PISA science: Implications for context-based science education. Journal of Research in Science Teaching, 46(8), 884-896. DOI: https://doi.org/10.1002/tea.20334

Gallagher, J. (1971). A broader base for science teaching. Science Education, 55(3), 329-338. DOI: https://doi.org/10.1002/sce.3730550312

Hurd, P. D. (1958). Science literacy: Its meaning for American schools. Educational Leadership, 16(1), 13-16.

Kesidou, S., \& Roseman, J. E. (2002). How well do middle school science programs measure up? Findings from project 2061's curriculum review. Journal of Research in Science Teaching, 39(6), 522-549. DOI: https://doi.org/10.1002/tea.10035

Kirk, K. (2018). What is the affective domain anyway? Retrieved May 8, 2018, from https://serc.carleton.edu/NAGTWorkshops/affective/intro.html

Kolstø, S. D. (2001). Scientific literacy for citizenship: Tools for dealing with controversial socio-scientific issues. Science Education, 85(3), 291-310. DOI: https://doi.org/10.1002/sce.1011

Millar, R. (1996). Toward a science curriculum for public understanding. School Science Review, 77(280), 7-18.

Miller, J. D. (1995). Scientific literacy for effective citizenship,” in R. E. Yager (ed.), Science/Technology/Society as reform in science education, pp. 185-204. New York: State University of New York Press.

Miller, J. D. (1998). The measurement of civic scientific literacy. Public Understanding of Science 7(3), $203-223$. DOI: https://doi.org/10.1088/0963-6625/7/3/001

Ministry of National Education [MoNE] (2004). Fen ve teknoloji dersi programı, ilkögrretim 4. -5. sinıf [Science and technology curriculum, 4th and 5th grades]. Ankara.

Ministry of National Education [MoNE] (2013). Fen bilimleri dersi ögretim programı, 3. 4. 5. 6. 7. ve 8. sinıflar) [Science curriculum, $3^{\text {rd }}, 4^{\text {th }}, 5^{\text {th }}, 6^{\text {th }}$, $7^{\text {th }}$, and $8^{\text {th }}$ grades]. Ankara.

Ministry of National Education [MoNE] (2017). Fen bilimleri dersi ögretim programı, 3. 4. 5. 6. 7. ve 8. sinıflar) [Science curriculum, $3^{\text {rd }}, 4^{\text {th }}, 5^{\text {th }}, 6^{\text {th }}$, $7^{\text {th }}$, and $8^{\text {th }}$ grades]. Ankara.

National Research Council [NRC]. (1996). National science education standards. Washington, DC: National Academy Press. 
Organisation for Economic Cooperation and Development [OECD]. (2013). PISA 2012 results: What makes schools successful? Resources, policies and practices (Volume IV). Paris: OECD Publishing. DOI: http://dx.doi.org/10.1787/9789264201156-en

Organisation for Economic Cooperation and Development [OECD]. (2016). PISA 2015 results (Volume I): Excellence and equity in education. Paris: OECD Publishing. DOI: https://dx.doi.org/10.1787/9789264266490-en

Organisation for Economic Cooperation and Development [OECD]. (2017). PISA 2015 Assessment and analytical framework: Science, reading, mathematic, financial literacy and collaborative problem solving. Paris: OECD Publishing. DOI: https://doi.org/10.1787/9789264281820-en

Rillero, P. (1998). Process skills and content knowledge. Science Activities, 35(3), 3-4. DOI: https://doi.org/10.1080/00368129809600910

Roberts, D. A. (2007). Scientific literacy/science literacy. In S. K. Abell \& N. G. Lederman (Eds.), Handbook of Research on Science Education (pp. 729-780). London: Lawrence Erlbaum Associates.

Rutherford, F. J., \& Ahlgren, A. (1990). Science for all Americans. New York: Oxford University Press.

Rudolph, J. L., \& Horibe, S. (2015). What do we mean by science education for civic engagement? Journal of Research in Science Teaching, 53(6), 805-820. DOI: https://doi.org/10.1002/tea.21303

Şad, S. N. (2012). Investigation of parental involvement tasks as predictors of primary students' Turkish, math, and science \& technology achievement. Eurasian Journal of Educational Research, 48, 135-154.

Van Driel, J., Beijaard, D., \& Verloop, N. (2001). Professional development and reform in science education: The role of teachers' practical knowledge. Journal of Research in Science Teaching, 38(2), 137-158. DOI: https://doi.org/10.1002/1098-2736(200102)38:2<137: AID-TEA1001>3.0.CO;2-U

Yager, R. (1986). Searching for excellence. Journal of Research in Science Teaching, 23(3), 209-217. DOI: https://doi.org/10.1002/tea.3660230305

Yorulmaz, Y. İ., Çolak, İ., \& Ekinci, C. E. (2017). An evaluation of PISA 2015 achievements of OECD countries within income distribution and education expenditures. Turkish Journal of Education, 6(4), 169-185. DOI: $10.19128 /$ turje. 329755 


\section{APPENDIX 1.}

Aspects, subdimensions, and practices in PISA scientific literacy framework

\begin{tabular}{|c|c|c|}
\hline Aspects & Subdimensions & Practices \\
\hline \multirow{5}{*}{ Contexts } & & Health and Disease \\
\hline & Personal & Natural Resources \\
\hline & Local & Environmental Quality \\
\hline & Global & Hazards \\
\hline & & Frontiers of Science and Technology \\
\hline \multirow{20}{*}{ Knowledge } & \multirow{3}{*}{$\begin{array}{l}\text { Knowledge of the Content } \\
\text { of Science }\end{array}$} & Physical systems \\
\hline & & Living System \\
\hline & & Earth and Space System \\
\hline & \multirow{7}{*}{ Procedural Knowledge } & The concept of variables \\
\hline & & Concepts of Measurements \\
\hline & & Ways of assessing and minimizing uncertainty \\
\hline & & Mechanisms to ensure the replicability of data \\
\hline & & Common ways of abstracting and representing data \\
\hline & & The control-of-variables \\
\hline & & The nature of an appropriate design for a scientific question \\
\hline & \multirow{10}{*}{ Epistemic Knowledge } & $\begin{array}{l}\text { The nature of scientific observations, facts, hypotheses, models, and } \\
\text { theories }\end{array}$ \\
\hline & & The purpose and goals of science as distinguished from technology \\
\hline & & The values of science \\
\hline & & The nature of reasoning \\
\hline & & How scientific claims are supported by data \\
\hline & & The function of different forms of empirical enquiry \\
\hline & & How measurement error affects the degree of confidence \\
\hline & & The use and role of abstract models and their limits \\
\hline & & The role of collaboration and critique \\
\hline & & $\begin{array}{l}\text { The role of scientific knowledge, along with other forms of } \\
\text { knowledge }\end{array}$ \\
\hline \multirow{15}{*}{ Competencies } & \multirow{5}{*}{$\begin{array}{l}\text { Explain phenomena } \\
\text { scientifically }\end{array}$} & Recall and apply appropriate scientific knowledge. \\
\hline & & Identify, use and generate explanatory models and representations \\
\hline & & Make and justify appropriate predictions \\
\hline & & Offer explanatory hypotheses \\
\hline & & $\begin{array}{l}\text { Explain the potential implications of scientific knowledge for } \\
\text { society }\end{array}$ \\
\hline & \multirow{5}{*}{$\begin{array}{l}\text { Evaluate and design } \\
\text { scientific enquiry }\end{array}$} & Identify the question explored in a given scientific study. \\
\hline & & Distinguish questions that could be investigated scientifically \\
\hline & & Propose a way of exploring a given question scientifically \\
\hline & & Evaluate ways of exploring a given question scientifically \\
\hline & & $\begin{array}{l}\text { Describe and evaluate how scientists ensure the reliability of data } \\
\text { and the objectivity and generalizability of explanations }\end{array}$ \\
\hline & \multirow{5}{*}{$\begin{array}{l}\text { Interpret data and evidence } \\
\text { scientifically }\end{array}$} & Transform data from one representation to another \\
\hline & & Analyze and interpret data and draw appropriate conclusions \\
\hline & & $\begin{array}{l}\text { Identify the assumptions, evidence, and reasoning in science-related } \\
\text { texts. }\end{array}$ \\
\hline & & $\begin{array}{l}\text { Distinguish between arguments that are based on scientific evidence } \\
\text { and theory and those based on other considerations. }\end{array}$ \\
\hline & & Evaluate scientific arguments and evidence from different sources \\
\hline \multirow{4}{*}{ Attitudes } & \multirow{4}{*}{$\begin{array}{l}\text { Interest in science } \\
\text { Valuing scientific } \\
\text { approaches to enquiry } \\
\text { Environmental awareness }\end{array}$} & \\
\hline & & \\
\hline & & \\
\hline & & \\
\hline
\end{tabular}


APPENDIX 2.

Typical objectives in the context aspect of science literacy

\begin{tabular}{|c|c|}
\hline Contexts & Typical Objectives \\
\hline \multicolumn{2}{|l|}{ Personal } \\
\hline Health and Disease & $\begin{array}{l}\text { Discuss what should be done to protect the health of the sense organs (Objective } \\
\text { number: F.3.2.1.3). }\end{array}$ \\
\hline Natural Resources & No objectives \\
\hline Environmental Quality & Be careful to be efficient in the use of resources (Objective number: F.4.6.1.1). \\
\hline Hazards & Discuss the dangers of moving objects in daily life (Objective number: F.3.3.2.3). \\
\hline $\begin{array}{l}\text { Frontiers of Science and } \\
\text { Technology }\end{array}$ & No objectives \\
\hline \multicolumn{2}{|l|}{ Local } \\
\hline Health and Disease & $\begin{array}{l}\text { Assume responsibility to reduce smoking in the close vicinity (Objective number: } \\
\text { F.4.2.1.6.). }\end{array}$ \\
\hline Natural Resources & $\begin{array}{l}\text { Discuss the separation of mixtures in terms of their contribution to national } \\
\text { economy and effective use of resources (Objective number: F.4.4.5.3.). }\end{array}$ \\
\hline Environmental Quality & $\begin{array}{l}\text { Discuss the effect of battery waste on environment and what should be done about } \\
\text { this (Objective number: F.3.7.2.2.). }\end{array}$ \\
\hline Hazards & No objectives \\
\hline Frontiers of Science and & Explain his/her ideas on the new applications of magnets (Objective number: \\
\hline Technology & F.4.3.2.4) \\
\hline \multicolumn{2}{|l|}{ Global } \\
\hline Health and Disease & No objectives \\
\hline Natural Resources & Discuss the importance of density of solid and liquid water for the livings \\
\hline Environmental Quality & $\begin{array}{l}\text { Explain the negative effects of light pollution on natural life and observation of } \\
\text { celestial bodies (Objective number: F.4.5.3.2). }\end{array}$ \\
\hline Hazards & $\begin{array}{l}\text { Discuss the causes and possible consequences of global climate change (Objective } \\
\text { number: F.8.6.3.5) }\end{array}$ \\
\hline $\begin{array}{l}\text { Frontiers of Science and } \\
\text { Technology }\end{array}$ & No objectives \\
\hline
\end{tabular}


APPENDIX 3.

Typical objectives in the knowledge aspect of science literacy

\begin{tabular}{|c|c|}
\hline Knowledge & Typical Objectives \\
\hline \multicolumn{2}{|l|}{ Knowledge of the Content of Science } \\
\hline Physical systems & $\begin{array}{l}\text { Classifies the substances according to their state (Objective number: } \\
\text { F.3.4.2.1). }\end{array}$ \\
\hline Living System & $\begin{array}{l}\text { Explain the basic functions of sensory organs. (Objective number: } \\
\text { F.3.2.1.2). }\end{array}$ \\
\hline Earth and Space System & $\begin{array}{l}\text { Explains the events that occurs as a result of Earth's motion (Objective } \\
\text { number F.4.1.2.2). }\end{array}$ \\
\hline \multicolumn{2}{|l|}{ Procedural Knowledge } \\
\hline The concept of variables & $\begin{array}{l}\text { Tests and predicts the variables that affects bulb brightness in an } \\
\text { electrical circuit. (Objective number F.5.7.2.1). }\end{array}$ \\
\hline Concepts of Measurements & $\begin{array}{l}\text { Compares the mass and volume of different substances by measuring } \\
\text { them (Objective number F.4.4.2.1).. }\end{array}$ \\
\hline $\begin{array}{l}\text { Ways of assessing and minimizing } \\
\text { uncertainty }\end{array}$ & No objectives \\
\hline $\begin{array}{l}\text { Mechanisms to ensure the replicability } \\
\text { of data }\end{array}$ & No objectives \\
\hline $\begin{array}{l}\text { Common ways of abstracting and } \\
\text { representing data }\end{array}$ & $\begin{array}{l}\text { Interpret the factors affecting the rate of photosynthesis by drawing } \\
\text { graphs (Objective number F.8.6.2.3) }\end{array}$ \\
\hline The control-of-variables & $\begin{array}{l}\text { Discover by doing experiment that the heat energy of a matter depends } \\
\text { on the type, mass, and temperature of the matter (Objective number } \\
\text { F.8.4.5.1) }\end{array}$ \\
\hline $\begin{array}{l}\text { The nature of an appropriate design for a } \\
\text { scientific question }\end{array}$ & No objectives \\
\hline \multicolumn{2}{|l|}{ Epistemic knowledge } \\
\hline $\begin{array}{l}\text { The nature of scientific observations, } \\
\text { facts, hypotheses, models, and theories }\end{array}$ & No objectives \\
\hline $\begin{array}{l}\text { The purpose and goals of science as } \\
\text { distinguished from technology }\end{array}$ & No objectives \\
\hline The values of science & No objectives \\
\hline The nature of reasoning & No objectives \\
\hline $\begin{array}{l}\text { How scientific claims are supported by } \\
\text { data }\end{array}$ & $\begin{array}{l}\text { Questions how the ideas about the concept of atom has changed from } \\
\text { past to present (Objective number F.7.4.1.2) }\end{array}$ \\
\hline $\begin{array}{l}\text { The function of different forms of } \\
\text { empirical enquiry }\end{array}$ & No objectives \\
\hline $\begin{array}{l}\text { How measurement error affects the } \\
\text { degree of confidence }\end{array}$ & $\begin{array}{l}\text { Discusses the ideas about the structure of the cell from past to present } \\
\text { by associating with technological developments. (Objective number } \\
\text { F.7.2.1.2) }\end{array}$ \\
\hline $\begin{array}{l}\text { The use and role of abstract models and } \\
\text { their limits }\end{array}$ & No objectives \\
\hline The role of collaboration and critique & No objectives \\
\hline $\begin{array}{l}\text { The role of scientific knowledge, along } \\
\text { with other forms of knowledge }\end{array}$ & No objectives \\
\hline
\end{tabular}




\section{APPENDIX 4.}

Typical objectives in the scientific competencies aspect of science literacy

\begin{tabular}{|c|c|}
\hline Scientific Competencies & Typical Objectives \\
\hline \multicolumn{2}{|l|}{ Explain phenomena scientifically } \\
\hline Recall and apply appropriate scientific & $\begin{array}{l}\text { Prepares solution by using the solutes and solvents from } \\
\text { daily life substances (Obiective number } F-4.2)\end{array}$ \\
\hline $\begin{array}{l}\text { Identify, use and generate explanatory models } \\
\text { and representations }\end{array}$ & $\begin{array}{l}\text { Designs an imaging tool using mirrors or lenses (Objective } \\
\text { number F.7.5.3.5) }\end{array}$ \\
\hline Make and justify appropriate predictions & $\begin{array}{l}\text { Predicts and tests the environments in which sound can } \\
\text { propagate. (Objective number F.6.5.1.1) }\end{array}$ \\
\hline Offer explanatory hypotheses & $\begin{array}{l}\text { Demonstrates the relationship between the sense of smell } \\
\text { and taste by designing experiment (Objective number } \\
\text { F.6.6.2.2) }\end{array}$ \\
\hline $\begin{array}{l}\text { Explain the potential implications of scientific } \\
\text { knowledge for society }\end{array}$ & $\begin{array}{l}\text { Discuss the separation of mixtures in terms of their } \\
\text { contribution to the national economy and the effective use } \\
\text { of resources. (Objective number F.4.4.5.3) }\end{array}$ \\
\hline \multicolumn{2}{|l|}{ Evaluate and design scientific enquiry } \\
\hline $\begin{array}{l}\text { Identify the question explored in a given } \\
\text { scientific study. }\end{array}$ & No objectives \\
\hline $\begin{array}{l}\text { Distinguish questions that could be investigated } \\
\text { scientifically }\end{array}$ & No objectives \\
\hline $\begin{array}{l}\text { Propose a way of exploring a given question } \\
\text { scientifically }\end{array}$ & $\begin{array}{l}\text { Offers solutions to prevent acid rain (Objective number } \\
\text { F.8.4.4.7) }\end{array}$ \\
\hline $\begin{array}{l}\text { Evaluate ways of exploring a given question } \\
\text { scientifically }\end{array}$ & No objectives \\
\hline $\begin{array}{l}\text { Describe and evaluate how scientists ensure the } \\
\text { reliability of data and the objectivity and } \\
\text { generalizability of explanations }\end{array}$ & No objectives \\
\hline \multicolumn{2}{|l|}{ Interpret data and evidence scientifically } \\
\hline $\begin{array}{l}\text { Transform data from one representation to } \\
\text { another }\end{array}$ & No objectives \\
\hline $\begin{array}{l}\text { Analyze and interpret data and draw appropriate } \\
\text { conclusions }\end{array}$ & $\begin{array}{l}\text { Discusses the importance of freshness and naturalness of } \\
\text { foods for a healthy life based on research data. (Objective } \\
\text { number F.4.2.1.3.) }\end{array}$ \\
\hline $\begin{array}{l}\text { Identify the assumptions, evidence, and reasoning } \\
\text { in science-related texts. }\end{array}$ & No objectives \\
\hline $\begin{array}{l}\text { Distinguish between arguments that are based on } \\
\text { scientific evidence and theory and those based on } \\
\text { other considerations. }\end{array}$ & No objectives \\
\hline $\begin{array}{l}\text { Evaluate scientific arguments and evidence from } \\
\text { different sources }\end{array}$ & No objectives \\
\hline
\end{tabular}

\section{APPENDIX 5.}

Typical objectives in the attitudes aspect of science literacy

\begin{tabular}{ll}
\hline \multicolumn{1}{c}{ Attitudes } & \multicolumn{1}{c}{ Typical Objectives } \\
\hline Interest in science & No objectives \\
Valuing scientific approaches to & Discuss the consequences of consanguineous marriages. (Objective number \\
enquiry & F.8.2.2.3) \\
Environmental awareness & Takes an active role in the cleaning of the environment. (Objective number \\
& F.3.6.2.2) \\
\hline
\end{tabular}




\section{TÜRKÇE GENIŞLETILMIŞ ÖZET}

Uluslararası Öğrenci Değerlendirme Programı (PISA) sonuçları, Türkiye’de eğitim gören 15 yaşındaki öğrencilerin bilgi toplumunun ihtiyaçlarını karşılayacak düzeyde fen okuryazarı olmadıklarına dair kanıtlar sağlamıştır. Türkiye'de 15 yaşındaki öğrencilerin büyük bir çoğunluğu $(\% 96,7)$ ortaöğretime devam etmektedir. Yani, Türkiye'de 15 yaşındaki öğrencilerin yaklaşık \%97'si, ilkokul ve ortaokul fen programının gereksinimlerini tamamlamıştır. Halen uygulanmakta olan Fen Bilimleri Dersi Öğretim Programı'nın (ilkokul ve ortaokul 3, 4, 5, 6, 7 ve 8. sinıflar) temel amaçlarından biri fen okuryazarı bireyler yetiştirmektir. Bu nedenle bu programı başarıyla tamamlamış öğrencilerden, fen okuryazarlık düzeyini değerlendirme amacı taşıyan PISA'da yüksek performans göstermeleri beklenir. $\mathrm{Bu}$ beklentinin aksine, 2015 PISA uygulamasında Türkiye fen okuryazarlık puanına göre 35 OECD ülkesi arasında 34. sırada yer almıştır. Ayrıca aynı sınavda ileri düzey bilimsel düşünme ve akıl yürütme becerileri gösterebilen öğrencilerin oranı, toplam öğrencilerin \% 1'inden daha azdır.

Türkiye'nin PISA'da elde ettiği görece başarısız sonuçlara bir takım makul açıklamalar getirmek mümkündür. Bunların bazıları eğitim-öğretimde ebeveyn desteğinin eksikliği, eğitime özgü kaynakların yetersizliği, okullar arası ciddi başarı farklılıkları ve öğrencileri ulusal sınavlara hazırlama kaygısı olarak sıralanabilir. Bunların yanında görece başarısızlığın bir nedeni de, fen okuryazarı öğrenci yetiştirmek için gereken bileşenleri tam karşılayamayan öğretim programları olabilir. Öğretmenler öğretim programlarını kazanımları belirlemek, içerikleri hazırlamak, etkinliklere karar vermek gibi farklı amaçlarla kullanırlar. Ayrıca öğretim programları bir öğretmenin ne öğreteceğine, nasıl öğreteceğine, ne zaman öğreteceğine, nerede öğreteceğine ve hatta neden öğreteceğine karar vermesi adına bir rehber niteliği taşır. $\mathrm{Bu}$ sebeple öğretim programlarının çeşitli yönleriyle analiz edilmesi önemlidir. $\mathrm{Bu}$ noktadan hareketle ortaya koyulan bu çalışmanın amacı, 2017 yılında yayımlanan ve halen uygulanmakta olan fen bilimleri öğretim programının fen okuryazarı öğrenci yetiştirme potansiyelini, PISA Fen Okuryazarlığı Değerlendirme Çerçevesi kullanarak analiz etmektir.

Fen okuryazarlığı, PISA Fen Okuryazarlığı Değerlendirme Çerçevesinde en genel haliyle bağlamlar, bilgi, yeterlikler ve tutumlar olmak üzere dört boyutta ele alınmaktadır. Her bir alt boyut, ilgili yapıyı ortaya koyacak şekilde detaylandırılmıştır. Örneğin bu çerçeve; yeterlikler boyutunu "olguları bilimsel olarak açıklama", "bilimsel sorgulama yöntemi tasarlama ve değerlendirme" ve "verileri ve bulguları bilimsel olarak yorumlama" olarak açıklamıştır. Bu çalışmada bu çerçeve kullanılarak 3. sınıftan 8 . sınıfa kadar uygulanmakta olan fen bilimleri öğretim programının bütün kazanımları analiz edilmiştir.

PISA Fen Okuryazarlığı Değerlendirme Çerçevesinde bağlamlar; kişisel, yerel/ulusal ve küresel olmak üzere üç farklı kategoride ele alınmıştır. Fen bilimleri öğretim programı bu açıdan incelendiğinde, programda yeterli miktarda bağlam temelli kazanım bulunmadığı dikkat çekmektedir. Öğretim programında bağlamı kişisel, yerel/ulusal ve küresel ölçekte sorunlar olan az sayıda kazanım vardır. $\mathrm{Bu}$ kazanımlar içinde kişisel bağlamda sağlık sorunlarını içeren kazanımlar, diğer kazanımlara kıyasla daha fazladır. Öte yandan küresel bağlamın alt boyutlarından çevresel kalite, kazanımlarda diğerlerinden daha fazla vurgulanmaktadır. Doğal kaynaklar ise en çok yerel/ulusal bağlamda vurgulanmaktadır.

PISA Fen Okuryazarlığı Değerlendirme Çerçevesinde bilgi; içerik bilgisi, süreçsel bilgi ve epistemik bilgi olmak üzere üç farklı kategoride ele alınmıştır. Fen bilimleri öğretim programı bilgi yönünden incelendiğinde 3. sınıftan 8. sınıfa kadar bütün sınıflarda süreçsel bilgi, içerik bilgisine kıyasla kazanımlarda daha az vurgulanmıştır. Süreçsel bilgi boyutunda yer alan ölçüm konuları, kazanımlar içerisinde diğer becerilere göre kendisine daha fazla yer bulabilmiştir. Diğer yandan kazanımlar epistemik bilgi yönünden oldukça yetersiz kalmıştır. Fen bilimleri dersi öğretim programında epistemik bilgiyi doğrudan geliştirmeye yönelik hiçbir kazanıma 4, 5, 6 ve 8 . sınıf düzeylerinde rastlanmamıştır.

PISA Fen Okuryazarlığı Değerlendirme Çerçevesinde yeterlikler; olguları bilimsel olarak açıklama, bilimsel sorgulama yöntemi tasarlama ve değerlendirme, verileri ve bulguları bilimsel olarak 
yorumlama olmak üzere üç farklı kategoride ele alınmıştır. Kazanımlarda en çok vurgulanan yeterlik, olguları bilimsel olarak açıklama şeklinde karşımıza çıkmaktadır. Diğer iki yeterlik öğretim programının kazanımlarında nadiren vurgulanmaktadır.

PISA Fen Okuryazarlığı Değerlendirme Çerçevesinde tutumlar; fen bilimlerine duyulan ilgi, bilimsel sorgulama yöntemlerine verilen değer ve çevresel farkındalık olmak üzere üç farklı kategoride ele alınmıştır. Program kazanımları bu üç kategori arasında en fazla çevresel farkındalığa odaklanmıştır. Kazanımlarda tutumlar açısından gözlemlenen önemli noktalardan biri de, farklı sınıf düzeylerinde fen bilimlerine duyulan ilgiye yönelik doğrudan vurgu yapan hiçbir kazanım bulunmamasıdır.

Özetle, bu çalışmanın iki genel bulgusu vardır: Ortaya konulan önemli bulgulardan ilki Türkiye'de uygulanan Fen Bilimleri Dersi Öğretim Programı'nın fen okuryazarlığının dört boyutunu dengeli bir şekilde yansıtmada yetersiz kaldığıdır. İkinci önemli bulgu ise fen bilimleri dersi öğretim programının daha çok içerik bilgisine yoğunlaştığıdır. İçerik bilgisi elbette herhangi bir programın önemli bileşenlerinden biridir. Fakat süreçsel ve epistemik bilgiye de içerik bilgisi ile kıyaslanabilecek ölçüde programda yer verilmelidir. Fen bilimleri dersi öğretim programı öğrencilere süreçsel ve epistemik bilgiyi de kazandırabilecek şekilde tasarlanmalıdır. Bu iki bilgi içerik bilgisiyle birlikte 21. yüzyılın ihtiyaç duyduğu becerilere sahip bireyleri yetiştirmede önem arz etmektedir. Günümüz sanayi dünyası hipotez kurabilen, bu hipotezleri sinayabilecek deneyler tasarlayabilen, amaca yönelik veri toplayabilen bireylere ihtiyaç duymaktadır. Bireyler bu becerileri en iyi zorunlu eğitim kademesi boyunca, özellikle fen bilimleri dersinde, ilk elden deneyimleyerek kazanabilirler. Bu deneyimleri kazandırmay hedefleyen bir fen bilimleri dersi öğretim programının olması, fen okuryazarı bireyler yetiştirmede atılacak önemli adımlardan biridir. Sonuç olarak, gelecekte yapılacak program güncelleme ve geliştirme çalışmalarında, fen okuryazarlığın dört boyutunu dengeli bir şekilde yansıtmak ve içerik bilgisinin yanında süreçsel ve epistemik bilgiye de benzer vurgular yapmak, PISA benzeri uluslararası sınavlarda başarımızı artıracağı gibi fen okuryazarı öğrenciler yetiştirmede mesafeleri daha hızlı kat etmemize olanak sağlayacaktır. 